\title{
Functional parameters indicative of mild cognitive impairment: a systematic review using instrumented kinematic assessment
}

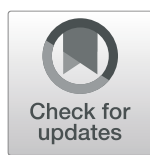

Iván José Fuentes-Abolafio ${ }^{3}$, Brendon Stubbs ${ }^{2,3,4}$, Luis Miguel Pérez-Belmonte ${ }^{5,6,7}$, María Rosa Bernal-López ${ }^{5,8}$, Ricardo Gómez-Huelgas ${ }^{5,8}$ and Antonio Cuesta-Vargas ${ }^{1,9^{*}}$ (D)

\begin{abstract}
Background: Patients with mild cognitive impairment (MCl) experience alterations of functional parameters, such as an impaired balance or gait. The current systematic review set out to investigate whether functional objective performance may predict a future risk of $\mathrm{MCl}$; to compare functional objective parameters in patients with $\mathrm{MCl}$ and a control group; and to assess changes in these parameters after different physical activity interventions.

Methods: Electronic databases, including PubMed, AMED, CINAHL, EMBASE, PEDro and Web of Science as well as grey literature databases, were searched from inception to February 2020. Cohort studies and Randomized Controlled Trials (RCTs) were included. The risk of bias of the included studies was assessed independently by reviewers using quality assessment checklists. The level of evidence per outcome was assessed using the GRADE criteria.

Results: Seventeen studies met inclusion criteria including patients with $\mathrm{MCl}$. Results from RCTs suggested that gait speed, gait variability and balance may be improved by different physical activity interventions. Cohort studies showed that slower gait speed, above all, under Dual Task (DT) conditions, was the main impaired parameter in patients with $\mathrm{MCl}$ in comparison with a Control Gorup. Furthermore, cohort studies suggested that gait variability could predict an incident MCl. Although most of included cohort studies reported low risk of bias, RCTs showed an unclear risk of bias.

Conclusions: Studies suggest that gait variability may predict an incident MCl. Moreover, different gait parameters, above all under DT conditions, could be impaired in patients with MCl. These parameters could be improved by some physical activity interventions. Although cohort studies reported low risk of bias, RCTs showed an unclear risk of bias and GRADE criteria showed a low level of evidence per outcome, so further studies are required to refute our findings.
\end{abstract}

Prospero: CRD42019119180.

Keywords: Mild cognitive impairment, Functional objective parameters, Instrumented assessment, Kinematics, Gait, Balance

\footnotetext{
* Correspondence: acuesta@uma.es

${ }^{1}$ Department of Physiotherapy, Faculty of Health Science, University

ofMálaga. Biomedical Research Institute of Malaga (IBIMA), Clinimetric Group

FE-14, Málaga, Spain. Av/ Arquitecto Peñalosa s/n (Teatinos Campus

Expansion), 29071 Malaga, Spain

${ }^{9}$ School of Clinical Sciences, Faculty of Health at the Queensland University

of Technology, Brisbane, Queensland, Australia

Full list of author information is available at the end of the article
}

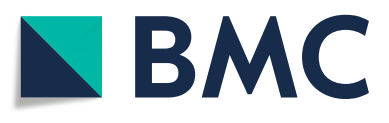

(c) The Author(s). 2020 Open Access This article is licensed under a Creative Commons Attribution 4.0 International License, which permits use, sharing, adaptation, distribution and reproduction in any medium or format, as long as you give appropriate credit to the original author(s) and the source, provide a link to the Creative Commons licence, and indicate if changes were made. The images or other third party material in this article are included in the article's Creative Commons licence, unless indicated otherwise in a credit line to the material. If material is not included in the article's Creative Commons licence and your intended use is not permitted by statutory regulation or exceeds the permitted use, you will need to obtain permission directly from the copyright holder. To view a copy of this licence, visit http://creativecommons.org/licenses/by/4.0/ The Creative Commons Public Domain Dedication waiver (http://creativecommons.org/publicdomain/zero/1.0/) applies to the data made available in this article, unless otherwise stated in a credit line to the data. 


\section{Background}

The global life expectancy is increasing in the last years. Consequently, morbidity, chronic individual diseases and the number of people affected by dementia are also increasing [1-5]. Thus, while dementias affected around 46.8 million people worldwide in 2016 [5], it is expected that in 2050 there will be 115-135 million people suffering from dementia $[6,7]$. There is an increase in the interest of mild cognitive impairment (MCI), defined as a clinical stage accounting for cognitive impairment that often precedes dementia [5, 8-17], and whose prevalence in adults of $\geq 65$ years old is $10-20 \%$, increasing this prevalence with age $[5,8]$.

Accepted diagnosis criteria of MCI reported that patients with MCI were characterized by an objective impairment of cognition that is often not severe enough to interfere with activities of daily living (ADL), instrumental activities of daily living (IADL) or in social or occupational functioning $[5,8,10-14,17-21]$. In the same way, Petersen [11] determined that patients with MCI presented very mild degrees of functional impairment that is difficult to distinguish from the functional problems of cognitively healthy individuals of the same age. However, patients with MCI may have problems in functional tasks [5] and it has been reported that these patients present the alteration of functional parameters, such as mobility, muscle strength, balance, gait dysfunction, or increased risk of falls [8, 22-26]. Slower gait speed has also been suggested as the mainly altered parameter in older populations [23-25, 27-32] which may be a marker for the preclinical stages of dementia [23, 30-33]. Thus, Doi et al. [34], Eggermont et al. [35] and Deshpande et al. [36] reported that slower gait speed could be indicative of MCI. Veronese et al. [30] showed an association between decreased gait speed and low performance in the Short Physical Performance Battery (SPPB) and cognitive decline. Other functional tests, such as Timed Up Go (TUG), Hand Grip Strength Test (HGST), Sit to Stand Test (STS), or Walking Speed Test (WST), have also been used to demonstrate the association between the performance on functional tests and MCI [22, 30, 37, 38].

However, Mirelman et al. [39] reported that patients with MCI could have functional alterations only identifiable through a kinematic analysis conducted in their case with an inertial sensor. In this way, Bahureksa et al. [40] revealed that kinematic gait parameters such as velocity, stride length, and stride time best discriminated patients with MCI from cognitively healthy individuals under single task (ST) conditions and, above all, under dual task (DT) conditions. Balance parameters such as anterior-posterior and medio-lateral sway position also were identified as significant discriminators [40]. Kinematic measurements are frequently used by physicians and researchers to quantify normal and pathological movements and could allow to identify altered objective functional parameters in patients with MCI [41]. The identification of changes in functional objective parameters could be relevant for targeting specific interventions aiming to prevent further functional decline or to improve the functionality of patients with MCI. Currently, no drug has been shown to be effective for MCI $[8,17,18,42]$. However, it has been reported that the combination of aerobic exercise, balance training, cognitive training, the Mediterranean diet and social commitment could reduce the risk of further cognitive impaiment and may improve cognition, mobility, balance and quality of life in patients with $\mathrm{MCI}[8,17,18,43,44]$. Considering this, the main objectives of this systematic review were (1) to examine if functional kinematic parameters may predict a future risk of MCI; (2) to compare these functional objective parameters in patients with MCI and a control group; (3) to assess longitudinal changes in these parameters after different physical activity interventions. The secondary objectives were (1) to assess the risk of bias of the included studies using The Newcastle-Ottawa Quality Assessment Scale (NOS) and The Cochrane Collaboration's tool; (2) to assess the level of evidence per outcome using the Grading of Recommendations Assessment, Development and Evaluation (GRADE).

\section{Methods}

This systematic review was carried out in accordance with the Preferred Reporting Items for Systematic Reviews and Meta-Analyses (PRISMA) statement [45]. The PRISMA checklist for this trial is available in supplementary appendix A. The systematic review protocol was registered at the International Prospective Register of Systematic Reviews (PROSPERO: CRD42019119180).

\section{Data sources and search strategy}

A systematic search was performed by two independent reviewers (IJ-FA and A-CV) from inception to February 2020 using optimised search strategies in the following electronic databases: PubMed, AMED, CINAHL, EMBASE, PEDro, Web of Science. A sensitive search strategy using relevant search terms that were developed from Medical Subject Headings (MeSH), and keywords from other similar studies were used: 'mild cognitive impaiment' (MeSH Terms), 'kinetics' (MeSH Terms), 'acceleromet"' (MeSH Terms), 'walking speed' (MeSH Terms), 'kinematic', 'kinematic analysis', 'Timed Up and Go', 'TUG', 'gait speed', 'gait speed test', 'walking speed test', 'short physical performance battery', 'SPPB', 'six minute walk test', ' 6 minute walk test', 'sit to stand test', 'single leg stance test', 'one leg stance test', 'functional reach test', 'romberg test' and 'functional task'. The complete search strategy report with all search terms is shown online in supplementary appendix B. The grey literature databases, such as New York Academy of Medicine Grey Literature Report, Grey Literature in Health Research and 
Open Grey were explored to detect any relevant unpublished data. References were exported, and duplicates were removed using citation management software (Mendeley desktop V.1.19.2).

\section{Eligibility criteria}

Only studies published in full-text papers were included. Abstracts in conference proceedings, poster presentations, notes or letters to the editor were excluded because they had insufficient detail to be evaluated. Each study had to meet the following inclusion criteria:

1. Cohort studies examining the relationship between functional kinematic parameters obtained by instrumented analysis (e.g., electronic walkways, wearable sensors, camera systems ...) and incident $\mathrm{MCI}$ or comparing these functional objective parameters between confirmed MCI and a Control Group formed by cognitively healthy individuals or people with Alzheimer Disease.

2. RCTs assessing longitudinal changes in functional objective parameters after different physical activity interventions.

3. Studies that included patients with MCI diagnosed by a specialist or which used validated diagnostic criteria (e.g., Petersen's et al. [11, 12, 14-16], Winblad et al. [13]), supported by a score of 0.5 on the Clinical Dementia Rating (CDR)) [46], $<26$ on the Montreal Cognitive Assessment (MoCa) [47, 48], or $>24$ MiniMental State Examination (MMSE) [48, 49], that permited to confirm the diagnosis of MCI.

4. Studies recruiting participants from any setting (general population, primary, secondary or tertiary care).

5. Studies written in English or Spanish.

The exclusion criteria were as follows:

1. All studies not including a longitudinal design (e.g cross-sectional studies).

2. Studies that included the relationship between functional parameters and incident MCI but did not include a kinematic instrumented analysis.

3. Studies exploring the relationship between functional kinematic parameters and cognitively healthy individuals or people with other neurologic diseases different from MCI.

4. Studies examining the relationship between $\mathrm{MCI}$ and other different kinematic parameters such as graphomotor functions, handwriting process variables, etc.

5. Studies that evaluated the relationship between functional kinematic parameters and brain structures in patients with MCI.
6. Studies that did not include validated diagnostic criteria of $\mathrm{MCI}$, did not specify how those patients with $\mathrm{MCI}$ were diagnosed or used a diagnosis based on a MMSE score of less than 24, which could be indicative of a greater dementia than the MCI [48-52].

\section{Study selection}

All studies identified by the search strategy were screened using the eligibility criteria previously specified. Two independent reviewers (IJ-FA and A-CV) carried out the first stage, which involved the screening of titles and abstracts to identify potentially relevant records. If the reviewers were unable to determine a study's eligibility based on title and abstract, the full text was retrieved. In this first stage, the two reviewers also excluded those documents that were not full-text papers. The same reviewers undertook the second stage, screening those articles that met all inclusion criteria. A short checklist was carried out to the present review in order to guide the selection of relevant studies (supplementary appendix C).

\section{Data extraction}

Two independent reviewers (IJ-FA and A-CV) extracted the following relevant data from each study: study details (first author, year of publication), study design, length of follow up, sample size and characteristics of participants (mean age), functional assessment or test used to assess functional parameters, physical activity intervention, instrument used to kinematic analysis and the methods used to diagnose or assess MCI.

\section{Quality assessment}

Two independent reviewers (IJ-FA and A-CV) assessed the risk of bias of the included cohort studies using the NOS [53]. The NOS is a reliable and valid tool for assessing the quality of non-randomized studies [53] and assigns up to a maximum of nine points for the least risk of bias in three domains: selection of study groups (four points); comparability of groups (two points); and ascertainment of exposure and outcomes (three points). The risk of bias of the included RCTs was assessed using The Cochrane Collaboration's tool [54]. The Cochrane Collaboration's tool includes seven domain or sources of risk or bias assessment: random sequence generation, allocation concealment, selective reporting, blinding of participants and personnel, blinding of outcome assessment, incomplete outcome data and other bias. For each domain, the risk is categorized as "low risk", "high risk" or "unclear risk". To assess the overall quality and the strength of the evidence per outcome, the GRADE approach was used [55]. In brief, the GRADE classification was carried out according to the presence, or not, of the following identified factors: (i) study design, (ii) risk of bias, (iii) inconsistency of results (iv) indirectness (v) 
imprecision, and (vi) other considerations (e.g. reporting bias). Two researchers (IJ-FA and A-CV) judged whether these factors were present for each outcome. The GRADE criteria was applied when each outcome was informed at least by two studies with the same design. The level of evidence per outcome based on the GRADE criteria is classified as: (1) high (further research is unlikely to change our confidence in the estimate of effect and there are no known or suspected reporting biases); (2) moderate (further research is likely to have an important effect on our confidence in the estimate of effect and might change the estimate); (3) low (further research is likely to have an important effect on our confidence in the estimate of effect and is likely to change the estimate); or (4) very low (we are uncertain about the estimate) [55].

\section{Data synthesis and analysis}

It was planned to conduct a meta-analysis of functional kinematic parameters such as gait, balance, posture or mobility, that could be indicative of MCI. However, due to an observed heterogeneity across studies in the type of design, methods of functional assessment, instruments used to conduct a kinematic analysis, duration of followup, statistical analysis, interventions and data presentation, the statistical pooling of results was deemed not appropriate. Therefore, a meta-analysis of results was not conducted, and a descriptive quantitative analysis was carried out. For this reason, a narrative synthesis of the most relevant summary measure and the main change from baseline was reported.

\section{Results}

\section{Study characteristics}

A total of 2239 citations were identified through electronic databases, with 0 additional studies identified through Grey Literature sources. One thousand one hundred fifty-seven titles and abstracts were screened, and 277 full-text papers were assessed. The number of studies retrieved from each database and the number of studies excluded in each screening phase are shown in Fig. 1. The full reference of excluded studies in the second stage $(n=260)$ is reported online in supplementary appendix D. The conflict of interests of included studies are shown online in supplementary appendix E. Of these, 17 studies (six RCTs, one pilot RCT study, one pilot cohort study, eight cohort studies and a reliability study) with a total of 478 participants with MCI and 1540 cognitively healthy individuals at baseline, were included in this review. The characteristics of the included RCTs and the main results are reported in Table 1. The results of cohort studies which compared functional objective parameters between confirmed $\mathrm{MCI}$ and a Control Group are reported in Table 2. The characteristics of cohort studies examining the relationship between functional kinematic parameters and incident MCI are showed in Table 3. Functional kinematic parameters were obtained by wearable sensors, tri-axial accelerometers, digital balance platform, motion and contact sensors, cameras and electronic walkways such as the GAIT Rite (see Table 4). The most frequently used diagnosis criteria of MCI were Petersen criteria $(n=7,41 \%)$ and the combination of the CDR $(n=9,53 \%)$ and MMSE $(n=11,65 \%)$ (see Table 5).

\section{Functional objective parameters after physical activity interventions}

RCTs showed that gait speed, cadence, stride length, smoothness of trunk movement in the vertical direction could be improved by aerobic exercises $(60 \%$ of aged predicted maximal heart rate), especially when aerobic exercises are performed alongside cognitive stimulation exercises or others physical exercises such as muscle strength training, postural balance retraining, or gait training $[56,57,62]$. Stride time and the total time to perform the TUG also could be improved by the same interventions [56, 57]. The center of mass sway in anterior-posterior and medial-lateral directions also may be improved by the balance training [58].

\section{Functional objective parameters predicting $\mathrm{MCl}$ or discriminating $\mathrm{MCl}$ patients from a control group}

Cohort studies suggested that a slower gait speed in ST condition and, above all, in DT conditions (counting backwards) was the parameter that best discriminated patients with MCI from cognitively healthy individuals $[63,67,68]$. Larger gait speed variability could also discriminate patients with $\mathrm{MCI}$ from cognitively healthy individuals $[64,67]$. However, the total time to perform the TUG and the different subtask of the TUG, was the parameter which best discriminated patients with $\mathrm{MCI}$ from patients with Alzheimer disease instead of the gait speed, because patients with MCI took lower time in performing the TUG [65]. On the other hand, cohort studies showed that larger gait variability or larger gait speed variability could predict an incident MCI [70, 71]. Decreased cadence and walk-regularity also were associated with an incident MCI [73].

\section{Methodological quality}

The methodological quality assessment of RCTs included is shown in supplementary Table 1 . In summary, RCTs showed an unclear risk of bias, being the allocation concealment and the blinding of outcome assessment the ítems worst defined. Most of the included cohort studies (60\%) reported low risk of bias while the rest (40\%) showed moderate risk of bias (supplementary Table 2). Comparability was the main source of bias in cohort 


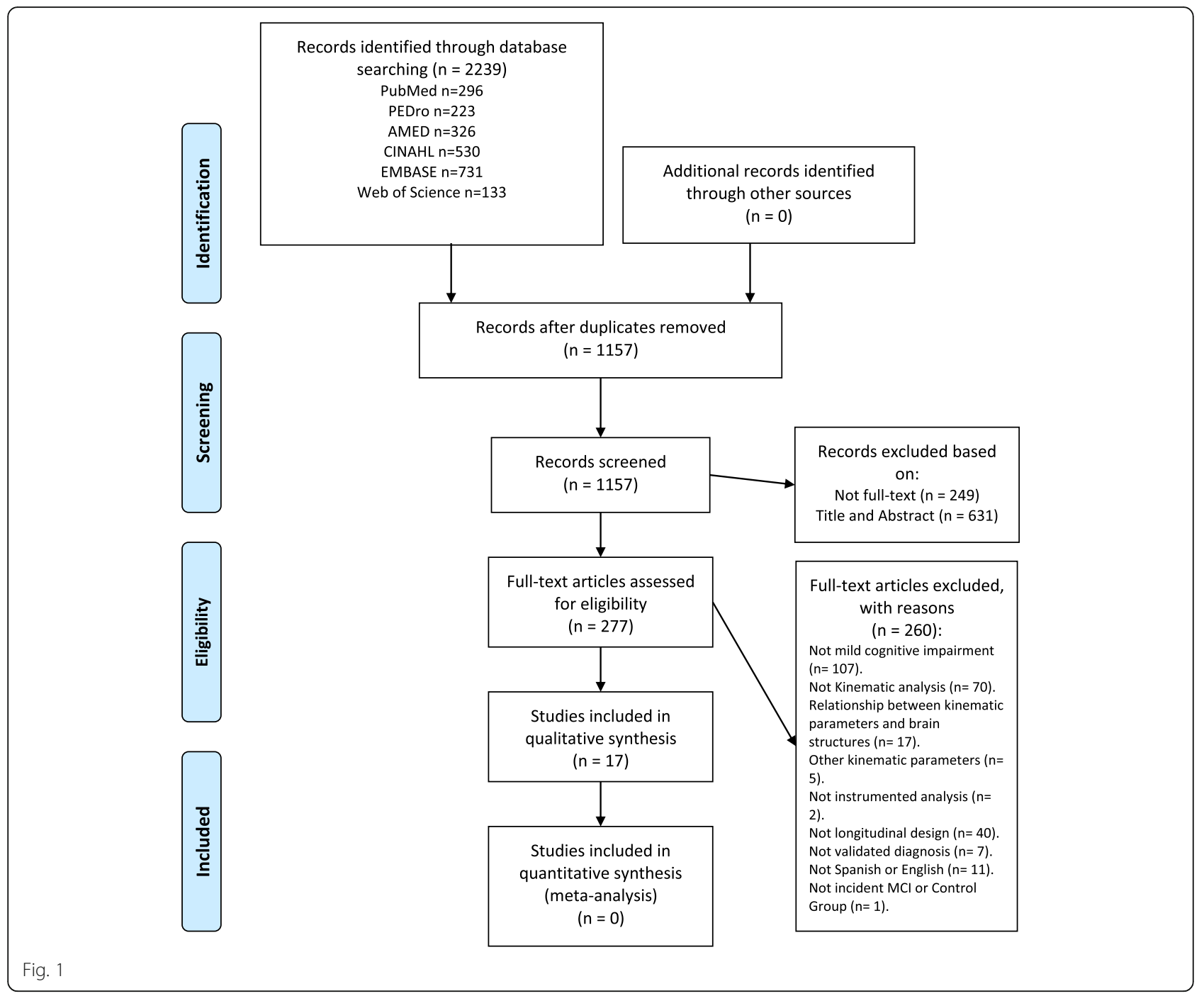

studies. The GRADE criteria showed a low level of evidence per outcome (supplementary Table 3).

\section{Discussion}

\section{Statement of principal findings and comparision with} others studies

The objective of this study was to review the current state of knowledge on the presence of functional kinematic parameters which may predict a future risk of $\mathrm{MCI}$, could discriminate patients with $\mathrm{MCI}$ from a control group and could even be improved after different physical activity interventions. To our knowledge, this is the first systematic review that provides a comprehensive overview of longitudinal studies (RCTs and cohort studies) using an instrumented kinematic assessment of functional task as outcome measures or as parameters which could be impaired in patients with MCI or may predict an incident MCI. Furthermore, most of the studies included in this review were published after 2015, which indicates the novelty of the topic [57-63, 65, 68, 70-73].

Cohort studies showed that slower gait speed in ST condition and DT conditions (counting backwards), as well as a larger gait speed variability were the parameters that best discriminated patients with $\mathrm{MCI}$ from cognitively healthy individuals $[64,67,68]$. Slower gait speed in ST and DT conditions, as well as the time to perform the TUG were the parameters that best discriminated patients with MCI from patients with Alzheimer disease $[63,65]$. Some studies have identified a slower gait speed in patients with $\mathrm{MCI}$ in comparison with cognitively healthy individuals $[25-27,29,34,35,40]$. Bahureksa et al. [40] also showed that a shorter stride length, a longer time to perform the stride (stride time) and a larger variability of these parameters may discriminate patients with MCI from cognitively healthy individuals. Verghese et al. [29] added a decreased cadence, a larger swing time variability, and a longer time to perform the swing 
Table 1 Summary of included RCT studies involved an Instrumented Functional Assessment as Outcome

\begin{tabular}{|c|c|c|c|c|c|c|c|c|}
\hline $\begin{array}{l}\text { Study (first } \\
\text { author } \\
\text { and year) }\end{array}$ & $\begin{array}{l}\text { Study } \\
\text { Design }\end{array}$ & $\begin{array}{l}\text { Study } \\
\text { Characteristics } \\
\text { (groups, } \\
\text { number of } \\
\text { participants, } \\
\text { mean age) }\end{array}$ & $\begin{array}{l}\mathrm{MCl} \\
\text { Diagnostic } \\
\text { Criteria }\end{array}$ & $\begin{array}{l}\text { Instrumented } \\
\text { Functional } \\
\text { Assessment }\end{array}$ & Instrument & Intervention & $\begin{array}{l}\text { Data } \\
\text { Collection } \\
\text { (follow- } \\
\text { up) }\end{array}$ & Main results in $\mathrm{MCl}$ \\
\hline $\begin{array}{l}\text { Doi et al. } \\
\text { [56], } 2013 .\end{array}$ & $\mathrm{RCT}$. & $\begin{array}{l}\text { Intervention } \\
\text { Group: } n=25 . \\
75.3 \text { years old. } \\
\text { Control Group: } \\
n=25.76 .8 \\
\text { years old. }\end{array}$ & $\begin{array}{l}\text { Petersen } \\
\text { Criteria } \\
{[11] .} \\
\text { MMSE > } 24 \\
\text { [49]. }\end{array}$ & $\begin{array}{l}\text { Walking at } \\
\text { preferred } \\
\text { speed ( } 11 \mathrm{~m} \\
\text { walkway). }\end{array}$ & $\begin{array}{l}\text { Tri-axial } \\
\text { accelerometer } \\
\text { attached to } \\
\text { the L3 } \\
\text { spinous. }\end{array}$ & $\begin{array}{l}\text { Intervention Group: } \\
\text { Aerobic exercise }(60 \% \text { of } \\
\text { aged predicted maximal } \\
\text { heart rate), endurance } \\
\text { walking, muscle strength } \\
\text { training, postural balance } \\
\text { retraining, and gait training } \\
\text { (90 min, 2/ week, } 6 \\
\text { months). } \\
\text { Control Group: } 2 \\
\text { Education classes about } \\
\text { health promotion. }\end{array}$ & $\begin{array}{l}\text { (T1) at } \\
\text { baseline; } \\
\text { (T2) six } \\
\text { months. }\end{array}$ & $\begin{array}{l}\uparrow \text { Gait speed } \downarrow \text { Stride time } \\
\text { and } \uparrow S t r i d e \text { length } \\
\text { in both groups***. } \\
\uparrow H R \text { in } V T \text { in the } \\
\text { Intervention group } \\
\uparrow \text { Gait speed, stride } \\
\text { length and HR in } V T \text { in } \\
\text { the Intervention group } \\
\text { vs control group**. }\end{array}$ \\
\hline $\begin{array}{l}\text { Donnezan } \\
\text { et al. [57], } \\
2018 \text {. }\end{array}$ & $\mathrm{RCT}$. & $\begin{array}{l}\text { PCT: } n=21 . \\
75.2 \text { years old. } \\
\text { PT: } n=18 . \\
77.1 \text { years old. } \\
\text { CT: } n=16 . \\
76.3 \text { years old. } \\
\text { Control Group: } \\
n=14.79 .2 \\
\text { years old. }\end{array}$ & $\begin{array}{l}\text { Petersen } \\
\text { Criteria } \\
\text { [11]. }\end{array}$ & $\begin{array}{l}\text { Walking } \\
\text { speed at } \\
\text { usual pace (6 } \\
\text { m) in ST and } \\
\text { DT } \\
\text { conditions. } \\
\text { WSC. } \\
\text { TUG. }\end{array}$ & $\begin{array}{l}\text { Electronic } \\
\text { walkway GAIT } \\
\text { Rite }^{\circledast} \text { (length: } \\
4.3 \text { m). }\end{array}$ & $\begin{array}{l}\text { PT: Aerobic training on } \\
\text { bikes ( } 60 \% \text { of aged } \\
\text { predicted maximal heart } \\
\text { rate). } \\
\text { CT: Cognitive exercises } \\
\text { (commercialized gaming } \\
\text { software). } \\
\text { PCT: Aerobic training on } \\
\text { bikes ( } 60 \% \text { of aged } \\
\text { predicted maximal heart } \\
\text { rate) + cognitive exercises. } \\
\text { Control Group: } \\
\text { Maintaining their usual } \\
\text { lifestyle. } \\
\text { All groups: Two one-hour } \\
\text { sessions/week, } 12 \text { weeks. }\end{array}$ & $\begin{array}{l}\text { (T1) at } \\
\text { baseline; } \\
\text { (T2) } \\
\text { twelve } \\
\text { weeks; } \\
\text { (T3) six } \\
\text { months. }\end{array}$ & $\begin{array}{l}\downarrow \text { Time to perform the } \\
\text { TUG }^{* * *} \text {. } \\
\uparrow \text { Gait speed**. } \\
\text { TUG improved after PT } \\
\text { and PCT } \\
\text { intervention***. } \\
\text { Gait speed in ST and } \\
\text { DT conditions } \\
\text { improved after PCT } \\
\text { training***. }\end{array}$ \\
\hline $\begin{array}{l}\text { Schwenk } \\
\text { et al. [58], } \\
2016 \text {. }\end{array}$ & $\begin{array}{l}\text { Pilot } \\
\text { RCT. }\end{array}$ & $\begin{array}{l}\text { Intervention: } \\
n=12.77 .8 \\
\text { years old. } \\
\text { Control: } n= \\
\text { 10. } 79.00 \text { years } \\
\text { old. }\end{array}$ & $\begin{array}{l}\text { Petersen } \\
\text { Criteria } \\
\text { [11]. }\end{array}$ & $\begin{array}{l}\text { Balance (to } \\
\text { stand for } 30 \mathrm{~s} \\
\text { with feet } \\
\text { close } \\
\text { together with } \\
\text { EO and EC. } \\
\text { Walking at } \\
\text { usual pace } \\
\text { and a fast } \\
\text { pace }(10 \mathrm{~m}) \text {. }\end{array}$ & $\begin{array}{l}\text { Wearable } \\
\text { sensors. }\end{array}$ & $\begin{array}{l}\text { Intervention: Balance } \\
\text { training (weight shifting } \\
\text { and virtual obstacle } \\
\text { crossing). Real-time visual/ } \\
\text { audio lower-limb motion } \\
\text { feedback provided from } \\
\text { wearable sensors 2/week, } \\
4 \text { weeks). } \\
\text { Control: No training. }\end{array}$ & $\begin{array}{l}\text { (T1) at } \\
\text { baseline; } \\
\text { (T2) four } \\
\text { weeks. }\end{array}$ & $\begin{array}{l}\downarrow C o M \text { sway in both } \\
\text { directions }(\mathrm{AP}, \mathrm{ML} \text { ) in } \\
\text { the intervention with } \\
\mathrm{EO}^{* *} \text {. }\end{array}$ \\
\hline
\end{tabular}

\begin{tabular}{|c|c|c|c|c|c|c|c|c|}
\hline $\begin{array}{l}\text { Fogarty } \\
\text { et al. [59], } \\
2016 .\end{array}$ & $\mathrm{RCT}$. & $\begin{array}{l}\text { MIP }+ \text { TTC: } n= \\
\text { 22. } 71.55 \text { years } \\
\text { old. } \\
\text { MIP: } \mathrm{n}=18 . \\
72.61 \text { years } \\
\text { old. }\end{array}$ & $\begin{array}{l}\text { Petersen } \\
\text { Criteria } \\
{[11] .} \\
\text { MMSE }>24 \\
\text { [49]. } \\
\text { MoCA < } 26 \\
{[47] .}\end{array}$ & $\begin{array}{l}\text { Walking at } \\
\text { usual pace in } \\
\text { ST and DT } \\
\text { conditions. } \\
\text { CTSIB with } \\
\text { EO and EC. }\end{array}$ & $\begin{array}{l}\text { GAITRite }^{\oplus} \\
\text { Portable } \\
\text { Walkway } \\
\text { System. } \\
\text { Digital } \\
\text { Balance } \\
\text { Platform. }\end{array}$ & $\begin{array}{l}\text { TTC: Taoist Tai Chi (2/week, } \\
90 \text { min/session, } 10 \text { weeks). } \\
\text { MIP: Education about } \\
\text { lifestyle factors that impact } \\
\text { memory and teaching of } \\
\text { memory strategies } \\
\text { (8 sessions). }\end{array}$ & $\begin{array}{l}\text { (T1) at } \\
\text { baseline; } \\
\text { (T2) ten } \\
\text { weeks; } \\
\text { (T3) } \\
\text { twenty- } \\
\text { two } \\
\text { weeks. }\end{array}$ & $\begin{array}{l}\text { No significant change } \\
\text { between groups in gait } \\
\text { variables, the DT cost } \\
\text { variables, or in the } \\
\text { amount of sway on the } \\
\text { balance measures. }\end{array}$ \\
\hline $\begin{array}{l}\text { Bae et Al. } \\
{[60], 2018 .}\end{array}$ & RCT. & $\begin{array}{l}\text { Intervention: } \\
n=41.75 .5 \\
\text { years old. } \\
\text { Control: } n= \\
\text { 42. } 76.4 \text { years } \\
\text { old. }\end{array}$ & $\begin{array}{l}\text { Winblad } \\
\text { Criteria } \\
\text { [13]. } \\
\text { MMSE > } 24 \\
\text { [49]. }\end{array}$ & $\begin{array}{l}\text { Maximum } \\
\text { hand grip } \\
\text { strength. } \\
\text { Walking } \\
\text { speed and } \\
\text { physical } \\
\text { activity (time } \\
\text { spent in } \\
\text { MVPA and } \\
\text { step count). }\end{array}$ & $\begin{array}{l}\text { Handheld } \\
\text { dynamometer. } \\
\text { Tri-axial } \\
\text { accelerometer. }\end{array}$ & $\begin{array}{l}\text { Intervention: Physical } \\
\text { activities (walking, muscle } \\
\text { strength training, stretching } \\
\text { etc) + cognitive exercises } \\
\text { (singing, playing a game, } \\
\text { etc) + social activities } \\
\text { (2/week, } 90 \text { min, } 24 \text { weeks). } \\
\text { Control: } 2 \text { Health } \\
\text { education classes } \\
\text { (90 mins each, during } \\
\text { the } 24 \text {-week). }\end{array}$ & $\begin{array}{l}\text { (T1) at } \\
\text { baseline; } \\
\text { (T2) six } \\
\text { months. }\end{array}$ & $\begin{array}{l}\downarrow \text { Time spent in MVPA } \\
\text { after intervention in the } \\
\text { control group**. } \\
\downarrow \text { Step count after } \\
\text { intervention in the } \\
\text { control group**. } \\
\text { Intervention Group kept } \\
\text { baseline parameters. }\end{array}$ \\
\hline $\begin{array}{l}\text { Delbroek } \\
\text { et al. [61], } \\
2017 .\end{array}$ & RCT. & $\begin{array}{l}\text { Intervention: } \\
\mathrm{n}=10.86 .9 \\
\text { years old. }\end{array}$ & $\begin{array}{l}\mathrm{MoCa}<26 \\
{[47] .}\end{array}$ & $\begin{array}{l}\text { TUG in ST } \\
\text { and DT } \\
\text { conditions. }\end{array}$ & $\begin{array}{l}\text { Inertial } \\
\text { measurement } \\
\text { units on the }\end{array}$ & $\begin{array}{l}\text { Intervention: Virtual reality } \\
\text { dual-task training using the } \\
\text { BioRescue (2/week, }\end{array}$ & $\begin{array}{l}\text { (T1) at } \\
\text { baseline; } \\
\text { (T2) six }\end{array}$ & $\begin{array}{l}\downarrow \text { Total time to perform } \\
\text { the TUG in the } \\
\text { intervention group }\end{array}$ \\
\hline
\end{tabular}


Table 1 Summary of included RCT studies involved an Instrumented Functional Assessment as Outcome (Continued)

\begin{tabular}{|c|c|c|c|c|c|c|c|c|}
\hline $\begin{array}{l}\text { Study (first } \\
\text { author } \\
\text { and year) }\end{array}$ & $\begin{array}{l}\text { Study } \\
\text { Design }\end{array}$ & $\begin{array}{l}\text { Study } \\
\text { Characteristics } \\
\text { (groups, } \\
\text { number of } \\
\text { participants, } \\
\text { mean age) }\end{array}$ & $\begin{array}{l}\mathrm{MCl} \\
\text { Diagnostic } \\
\text { Criteria }\end{array}$ & $\begin{array}{l}\text { Instrumented } \\
\text { Functional } \\
\text { Assessment }\end{array}$ & Instrument & Intervention & $\begin{array}{l}\text { Data } \\
\text { Collection } \\
\text { (follow- } \\
\text { up) }\end{array}$ & Main results in $\mathrm{MCl}$ \\
\hline & & $\begin{array}{l}\text { Control: } n= \\
\text { 10. } 87.5 \text { years } \\
\text { old. }\end{array}$ & & & $\begin{array}{l}\text { ankles, wrists } \\
\text { and sternum. }\end{array}$ & $\begin{array}{l}18-30 \text { min, } 6 \text { weeks). } \\
\text { Control: No training. }\end{array}$ & weeks. & during ST condition**. \\
\hline $\begin{array}{l}\text { Liao et al. } \\
\text { [62], } 2019 .\end{array}$ & $\mathrm{RCT}$. & $\begin{array}{l}\text { Intervention: } \\
n=18.75 .5 \\
\text { years old. } \\
\text { Control: } n= \\
\text { 16. } 73.1 \text { years } \\
\text { old. }\end{array}$ & $\begin{array}{l}\mathrm{MoCa}<26 \\
{[47] .}\end{array}$ & $\begin{array}{l}\text { Walking at } \\
\text { preferred } \\
\text { Speed in ST } \\
\text { and DT } \\
\text { conditions. }\end{array}$ & $\begin{array}{l}\text { GAIT Up } \\
\text { System. }\end{array}$ & $\begin{array}{l}\text { Intervention: VR-based } \\
\text { physical and cognitive } \\
\text { training ( } 60 \text { min, 3/week, } \\
12 \text { weeks). } \\
\text { Control: Combined } \\
\text { physical (resistance, } \\
\text { aerobic [50-75\% heart rate] } \\
\text { and balance exercises) and } \\
\text { cognitive exercises. }\end{array}$ & $\begin{array}{l}\text { (T1) at } \\
\text { baseline; } \\
\text { (T2) three } \\
\text { months. }\end{array}$ & $\begin{array}{l}\uparrow \text { Gait speed and stride } \\
\text { length in ST and DT } \\
\text { conditions in VR } \\
\text { group** } \\
\uparrow \text { Gait speed and } \\
\text { cadence only in ST in } \\
\text { Control Group** } \\
\text { No differences between } \\
\text { groups*. }\end{array}$ \\
\hline
\end{tabular}

MCI Mild cognitive impairment, RCT Randomized Controlled Trial, aMCI Amnestic mild cognitive impairment, MMSE Mini-mental State Examination, L3 Third lumbar vertebra level, $H R$ Harmonic ratio that represent the smoothness of trunk movement, VT Vertical direction, $P C T$ Combined simultaneous Physical and Cognitive Training, PT Physical Training, CT Cognitive Training, ST Single task, DT Dual task. WSC Walking Stroop Carpet test, TUG Timed Up an Go Test, EO Eyes open, EC Eyes closed, CoM Center of mass, AP Anterior-posterior, ML Medial-lateral, MIP Memory Intervention Program, TTC Taoist Tai Chi, MoCA Montreal Cognitive Assessment, CTSIB Clinical Test of Sensory Integration and Balance, MVPA Moderate-to-Vigorous Physical Activity, VR Virtual Reality $\uparrow$ Increased. $\downarrow$ Decreased

${ }^{*} p>0.05 .{ }^{* *} p<0.05 .{ }^{* * *} p<0.001$

phase, stance phase and double support phase, as parameters which could be impaired in patients with MCI in comparison with cognitively healthy controls. A previous systematic review also demonstrated slower gait speed and larger gait speed variability in patients with $\mathrm{MCI}$ than in cognitively healthy individuals [74].

Thus, larger gait variability, above all in DT conditions, could be associated with MCI [26]. In our review, cohort studies showed that a larger gait variability or a larger gait speed variability could predict an incident MCI [70, 71]. Several studies have also reported that a slow gait speed and a larger gait variability seem to be the main parameters which could predict a future cognitive decline and may be useful in the early detection of MCI [24, 26, 28, 30-33, 36, 75]. Decreased cadence, walk-regularity and slower gait speed were other kinematic parameters in our review which may be associated with an incident MCI [70, 73].

In the current review, RCTs suggested that gait speed, stride length, stride time, balance and the time to perform the TUG may be improved by aerobic exercises (60\% of aged predicted maximal heart rate), especially when aerobic exercises are performed alongside cognitive stimulation exercises or others physical exercises such as muscle strength training, postural balance retraining, or gait training $[56-58,61]$. Nevertheless, sample sizes were small in most of the included studies [56-59, 61, 62]. A previous study showed limited evidence on intervention effects on stride time variability [76] although this parameter seems to be a important predictor of MCI [58, 61, 63]. The combination of aerobic exercise, balance training and cognitive training could help reduce the risk of further cognitive impairment and may improve cognition, mobility, balance and quality of life [41, 43]. Furthermore, some systematic reviews and meta-analysis showed that aerobic and resistance (strength) exercises, join cognitive training could improve cognitive function, activities in daily living and $\operatorname{mood}[77-80]$.

\section{Strengths and weaknesses of the study}

The strengths of this systematic review included the use of a pre-specified protocol registered on PROSPERO, the PRISMA checklist, the NOS and The Cochrane Collaboration's tool to determine the risk of bias of included studies and the GRADE criteria to assess the level of evidence per outcome. Furthermore, this review only included studies which provided a validated diagnostic criteria of MCI. There are several limitations that should be mentioned. First, it is possible that some studies were not identified, although we conducted a robust search strategy in order to avoid it. Second, the lack of uniformity among the study design (e.g. walking distance, variables measured, different instruments used in kinematic analysis) should be taken into account when interpreting the results. In the literature, it has been demonstrated that participant walking strategy changes with walking distance, resulting in a significant effect on gait variability [81], so walking distance could be highly relevant in order to measure gait variability as a marker for MCI. Furthermore, studies did not report the reliability, validity or responsiveness of the instruments used in kinematic analysis, so we could not show what motion capture instrument is the most effective to perform the kinematic analysis. Third, RCTs reported an "unclear" risk of bias, so no firm conclusions should be drawn. 
Table 2 Summary of included Cohort studies which compared Instrumented Objective Functional Parameters between Confirmed $\mathrm{MCl}$ and a Control Group

\begin{tabular}{|c|c|c|c|c|c|c|c|}
\hline $\begin{array}{l}\text { Study (first } \\
\text { author } \\
\text { and year) }\end{array}$ & Study Design & $\begin{array}{l}\text { Study } \\
\text { Characteristics } \\
\text { (groups, number } \\
\text { of participants, } \\
\text { mean age) }\end{array}$ & $\begin{array}{l}\mathrm{MCl} \\
\text { Diagnostic } \\
\text { Criteria }\end{array}$ & $\begin{array}{l}\text { Instrumented Functional } \\
\text { Assessment }\end{array}$ & Instrument & $\begin{array}{l}\text { Data } \\
\text { Collection } \\
\text { (follow- } \\
\text { up) }\end{array}$ & Main results in $\mathrm{MCl}$ \\
\hline $\begin{array}{l}\text { Gillain } \\
\text { et al. [63], } \\
2015 .\end{array}$ & Pilot Cohort Study. & $\begin{array}{l}-\mathrm{MCl}+: n=9 . \\
74.44 \text { years old. } \\
-\mathrm{MCl}-: n=4 . \\
70.00 \text { years old. }\end{array}$ & $\begin{array}{l}\text { Petersen } \\
\text { Criteria } \\
{[15] .} \\
\text { CDR }=0.5 \\
{[46] .} \\
\text { MMSE }>24 \\
{[49] .}\end{array}$ & $\begin{array}{l}\text { Walking at preferred speed } \\
(40 \mathrm{~m}) \text { in ST and DT } \\
\text { conditions. }\end{array}$ & $\begin{array}{l}\text { Tri-axial accelerometric } \\
\left(\text { Locometrix }{ }^{\oplus}\right) \text { attached } \\
\text { to the L3. }\end{array}$ & $\begin{array}{l}\text { (T1) at } \\
\text { baseline; } \\
\text { (T2) one } \\
\text { year; } \\
\text { (T3) four } \\
\text { years. }\end{array}$ & $\begin{array}{l}\uparrow \text { Gait speed in ST and in } \\
\text { DT in } \mathrm{MCl} \text { - than in } \mathrm{MCl}+{ }^{* *} \text {. } \\
\uparrow S y m m e t r y \text { in DT in } \mathrm{MCl}- \\
\text { than in } \mathrm{MCl}+{ }^{* *} \text {. } \\
\downarrow \text { Gait performances in DT } \\
\text { compared to ST. }\end{array}$ \\
\hline $\begin{array}{l}\text { Hayes } \\
\text { et al. [64], } \\
2008 .\end{array}$ & $\begin{array}{l}\text { Transversal and } \\
\text { longitudinal study } \\
\text { (paired comparison } \\
\text { and repeated measure } \\
\text { ANOVA) }\end{array}$ & $\begin{array}{l}\text { - Healthy Group: } \\
\quad n=7.90 \text { years } \\
\text { old. } \\
\text { - MCl: } n=7 \text {. } \\
\text { 88.44 years old. }\end{array}$ & $\begin{array}{l}\text { All: MMSE } \\
\geq 24 \text { [49]. } \\
\text { Control: } \\
\text { CDR }=0 \\
\text { [46]. } \\
\text { MCl: } \\
\text { CDR }=0.5 \\
{[46] .}\end{array}$ & $\begin{array}{l}\text { Activity in the home, amount } \\
\text { of variance in activity, tracking } \\
\text { visitors, absences from the } \\
\text { home, and walking speed. }\end{array}$ & $\begin{array}{l}\text { Motion sensors and } \\
\text { magnetic contact } \\
\text { sensors placed in home, } \\
\text { and wireless contact } \\
\text { switches. }\end{array}$ & $\begin{array}{l}\text { (T1) mean } \\
\text { of } 315 \\
\text { days. }\end{array}$ & $\begin{array}{l}\uparrow C O V \text { in the median gait } \\
\text { speed in } \mathrm{MCl} \text { compared } \\
\text { with Healthy group }{ }^{* *} \text {. } \\
\uparrow 24-h \text { wavelet variance in } \\
\mathrm{MCl} \text { Group than Healthy } \\
\text { Group ( } \uparrow \text { variance in the } \\
\text { day-to-day pattern of } \\
\text { activity) }{ }^{* *} \text {. }\end{array}$ \\
\hline $\begin{array}{l}\text { Ansai et al. } \\
\text { [65]. } 2018 .\end{array}$ & $\begin{array}{l}\text { Longitudinal } \\
\text { prospective study. }\end{array}$ & $\begin{array}{l}\text { - AD: } n=37 \\
\text { 78.5 years old. } \\
\text { - MCl: } n=38 . \\
74.75 \text { years old. }\end{array}$ & $\begin{array}{l}\text { MCl Group: } \\
\text { CDR }=0.5 \\
\text { [46]. } \\
\text { MMSE > } 24 \\
\text { [49]. } \\
\text { Pfeffer [66]. }\end{array}$ & TUG & $\begin{array}{l}\text { Qualisys ProReflex } \\
\text { motion analysis system } \\
\text { with seven cameras. }\end{array}$ & $\begin{array}{l}\text { (T1) at } \\
\text { baseline; } \\
\text { (T2) six } \\
\text { months. }\end{array}$ & $\begin{array}{l}\downarrow \text { Total time to perform the } \\
\text { TUG in } \mathrm{MCl} \text { vs } A D^{* *} \text {. } \\
\uparrow \text { Gait speed in the walking } \\
\text { forward subtask in } \mathrm{MCl} \text { vs } \\
\mathrm{AD} \mathrm{D}^{* *} \text {. } \\
\downarrow \text { Time in the turn subtask } \\
\text { in } \mathrm{MCl} \text { vs } A D^{* *} \text {. } \\
\uparrow \text { Gait speed in the walking } \\
\text { back subtask in } \mathrm{MCl} \text { vs } \\
\mathrm{AD}^{* *} \text {. } \\
\downarrow \text { Time in the turn-to-sit } \\
\text { subtask in MCl vs } A D^{* *} \text {. }\end{array}$ \\
\hline $\begin{array}{l}\text { Dodge } \\
\text { et al. [67], } \\
2012 \text {. }\end{array}$ & $\begin{array}{l}\text { Longitudinal } \\
\text { (Latent trajectory } \\
\text { model). Part of cohort } \\
\text { study. }\end{array}$ & $\begin{array}{l}\text { - aMCl: } n=8.84, \\
5 \text { years old. } \\
\text { - naMCl: } n=31 . \\
\text { 83.8 years old. } \\
\text { - Healthy Group: } \\
n=54.84 .9 \\
\text { years old. }\end{array}$ & $\begin{array}{l}\text { ALL: } \\
\text { CDR } \leq 0.5 \\
\text { [46]. } \\
\text { MMSE > } 24 \\
\text { [49]. } \\
\text { MCl: } \\
\text { Petersen } \\
\text { Criteria } \\
\text { [11]. }\end{array}$ & $\begin{array}{l}\text { Walking speed and its } \\
\text { variability; total daily activity, } \\
\text { visitors and time out of home. }\end{array}$ & $\begin{array}{l}\text { Motion sensors and } \\
\text { contact sensors fixed in } \\
\text { the homes, and wireless } \\
\text { contact switches. }\end{array}$ & $\begin{array}{l}\text { (T1) at } \\
\text { baseline; } \\
\text { (T2) mean } \\
\text { of } 2.6 \pm \\
1.0 \text { years. }\end{array}$ & $\begin{array}{l}\text { Slow gait speed in } \\
\text { naMCl**. } \\
\uparrow o r \downarrow \text { baseline COV of gait } \\
\text { speed groups in naMCl. } \\
\downarrow \text { Gait speed in } \mathrm{MCl} \text { than in } \\
\text { Healthy Group**. } \\
\uparrow C O V \text { of gait speed in } \mathrm{MCl} \\
\text { than in Healthy Group }{ }^{* *} \text {. }\end{array}$ \\
\hline $\begin{array}{l}\text { Pieruccini- } \\
\text { Faria et al. } \\
\text { [68], } 2018 .\end{array}$ & $\begin{array}{l}\text { Part of a prospective } \\
\text { cohort study. }\end{array}$ & $\begin{array}{l}\text { - } \mathrm{MCl}: n=52 . \\
73.7 \text { years old. } \\
\text { - Healthy Group: } \\
n=27.71 .7 \\
\text { years old. }\end{array}$ & $\begin{array}{l}\text { Control: } \\
- \text { CDR =0 } \\
\text { [46]. } \\
- \text { MoCA } \\
\geq 27 \text { [47]. } \\
\text { MCl: } \\
- \text { CDR }=0.5 \\
\text { [46]. } \\
- \text { MoCA < } \\
26[47] .\end{array}$ & $\begin{array}{l}\text { Walking speed in ST and DT } \\
\text { conditions. }\end{array}$ & $\begin{array}{l}\text { Electronic walkway } \\
\text { (lenght: } 6 \mathrm{~m} \text { ) embedded } \\
\text { with sensors. }\end{array}$ & $\begin{array}{l}\text { (T1) at } \\
\text { baseline; } \\
\text { (T2) two } \\
\text { years; } \\
\text { (T3) four } \\
\text { years; } \\
\text { (T4) five } \\
\text { years. }\end{array}$ & $\begin{array}{l}\downarrow \text { Gait speed in DT } \\
\text { conditions in } \mathrm{MCl}^{* *} \text {. } \\
\downarrow \text { Step length adjustments } \\
\text { in DT conditions in } \mathrm{MCl}^{* *} \text {. } \\
\downarrow \text { Gait speed in } \mathrm{MCl}^{* *} \text {. }\end{array}$ \\
\hline $\begin{array}{l}\text { Montero- } \\
\text { Odasso } \\
\text { et al. [69], } \\
2009 .\end{array}$ & Reliability study. & $\begin{array}{l}\text { - MCl: } n=11 \\
\text { 76.6 years old. }\end{array}$ & $\begin{array}{l}\text { Petersen } \\
\text { Criteria } \\
{[14] .} \\
\text { CDR }=0.5 \\
{[46] .} \\
\text { MoCA < } 26 \\
{[47] .} \\
\text { MMSE }>24 \\
{[49] .}\end{array}$ & $\begin{array}{l}\text { Gait performance under ST } \\
\text { and DT conditions. }\end{array}$ & $\begin{array}{l}\text { Electronic walkway } \\
\text { (GAITRite }{ }^{\oplus} \text { System. } \\
\text { Lenght: } 6 \text { m). }\end{array}$ & $\begin{array}{l}\text { (T1) at } \\
\text { baseline; } \\
\text { (T2) one } \\
\text { week. }\end{array}$ & $\begin{array}{l}\downarrow \text { Mean gait speed under } \\
\text { DT conditions**. } \\
\uparrow \text { Gait variability on stride } \\
\text { time, step time, and double } \\
\text { support time under DT } \\
\text { conditions }^{* *} \text {. }\end{array}$ \\
\hline
\end{tabular}

MCI Mild cognitive impairment, $M C l+M C l$ who will develop $A D, M C l-M C l$ who will not develop AD, CDR Clinical Dementia Rating score, $M M S E$ Mini-mental State Examination, ST Simple task, DT Dual task, L3 Third lumbar vertebra level, ANOVA Analysis of Variance, COV Coefficient of variation, AD Alzheimer Disease, TUG Timed Up an Go Test, aMCl Amnestic mild cognitive impairment, naMCI Non-amnestic mild cognitive impairment, MoCA Montreal Cognitive Assessment, GV Gait velocity $\uparrow$ Higher. $\downarrow$ Lower

${ }^{*} p>0.05 .{ }^{* *} p<0.05 .{ }^{* * *} p<0.001$

\section{Implications for clinical practice}

Our results showed kinematic gait parameters which could be impaired and may predict an incident MCI. This is an important step forward in developing a clinically validated approach for measuring MCI related functional deficits which could predict a future risk of MCI and could even help its early diagnosis, although further studies are required in order to validate the 
Table 3 Summary of included Cohort studies examined the relationship between Kinematic Functional Parameters and an incident

\begin{tabular}{|c|c|c|c|c|c|c|c|}
\hline $\begin{array}{l}\text { Study } \\
\text { (first } \\
\text { author } \\
\text { and year) }\end{array}$ & Study Design & $\begin{array}{l}\text { Study } \\
\text { Characteristics } \\
\text { (groups, number } \\
\text { of participants, } \\
\text { mean age) }\end{array}$ & $\begin{array}{l}\mathrm{MCl} \\
\text { Diagnostic } \\
\text { Criteria }\end{array}$ & $\begin{array}{l}\text { Instrumented } \\
\text { Functional Assessment }\end{array}$ & Instrument & $\begin{array}{l}\text { Data } \\
\text { Collection } \\
\text { (follow-up) }\end{array}$ & Main results in $\mathrm{MCl}$ \\
\hline $\begin{array}{l}\text { Byun } \\
\text { et al. [70], } \\
2018 .\end{array}$ & $\begin{array}{l}\text { Prospective cohort } \\
\text { study. }\end{array}$ & $\begin{array}{l}\text { Healty: } n=91 \\
67.3 \text { years old. }\end{array}$ & $\begin{array}{l}\text { Not } \\
\text { diagnosis } \\
\text { MCl at } \\
\text { baseline: } \\
\text { CDR }=0 \\
\text { [46]. } \\
\text { MMSE > } 24 \\
\text { [49]. } \\
\text { Winblad } \\
\text { Criteria [13] } \\
\text { for } \\
\text { diagnosis } \\
\text { of MCl. }\end{array}$ & $\begin{array}{l}\text { Walking at usual pace } \\
(20 \mathrm{~m}) \text {. }\end{array}$ & $\begin{array}{l}\text { Tri-axial } \\
\text { accelerometer } \\
\text { (FITMETER }^{\oplus} \text { ) } \\
\text { at the level of the } \\
\text { 3rd-4th lumbar } \\
\text { vertebra. }\end{array}$ & $\begin{array}{l}\text { (T1) at } \\
\text { baseline; } \\
\text { (T2) } 2 \\
\text { years; } \\
\text { (T3) } \\
\text { median } \\
\text { duration } \\
\text { was } 47.1 \\
\text { months. }\end{array}$ & 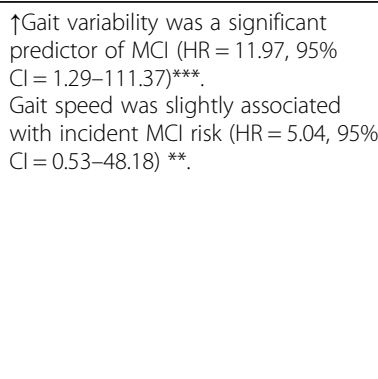 \\
\hline $\begin{array}{l}\text { Akl et al. } \\
\text { [71], } 2015 .\end{array}$ & $\begin{array}{l}\text { Longitudinal study } \\
\text { (trajectory with time } \\
\text { window vector } \\
\text { machines and random } \\
\text { forests). }\end{array}$ & $\begin{array}{l}\text { Older adults: } n= \\
97 . \mathrm{NS}, 70 \text { years } \\
\text { old and }+.\end{array}$ & $\begin{array}{l}\text { Cognitively } \\
\text { Healthy: } \\
- \text { CDR < } 0.5 \\
\text { [46]. } \\
- \text { MMSE }> \\
24 \text { [49]. } \\
\text { MCl: } \\
- \text { CDR }=0.5 \\
{[46] .} \\
- \text { MMSE > } \\
24[49] .\end{array}$ & $\begin{array}{l}\text { Walking speed and } \\
\text { general activity in the } \\
\text { home. Visitors and } \\
\text { absences from the } \\
\text { home. }\end{array}$ & $\begin{array}{l}\text { Motion sensors } \\
\text { and wireless } \\
\text { contact switches } \\
\text { placed in the } \\
\text { home. }\end{array}$ & $\begin{array}{l}\text { (T1) at } \\
\text { baseline; } \\
\text { (T2) one } \\
\text { year; } \\
\text { (T3) two } \\
\text { years; } \\
\text { (T4) three } \\
\text { years. }\end{array}$ & $\begin{array}{l}\text { Trajectories of weekly gait speed, } \\
\text { COV of the gait speed, COV of the } \\
\text { morning and evening gait speeds } \\
\text { could detect MCI in older adults. }\end{array}$ \\
\hline $\begin{array}{l}\text { Akl et al. } \\
{[72], 2015 .}\end{array}$ & $\begin{array}{l}\text { Longitudinal study } \\
\text { (linear regression). }\end{array}$ & $\begin{array}{l}\text { Older adults: } n= \\
15 . \mathrm{NS}, 70 \text { years } \\
\text { old and }+.\end{array}$ & $\begin{array}{l}\text { Cognitively } \\
\text { Healthy: } \\
- \text { CDR }<0.5 \\
{[46] \text {. }} \\
\text { MCl: } \\
-C D R=0.5 \\
{[46] .}\end{array}$ & Walking speed in home. & $\begin{array}{l}\text { Motion } \\
\text { sensors on the } \\
\text { ceiling in areas } \\
\text { such as a hallway } \\
\text { or a corridor. }\end{array}$ & $\begin{array}{l}\text { (T1) at } \\
\text { baseline; } \\
\text { (T2) one } \\
\text { year; } \\
\text { (T3) two } \\
\text { years; } \\
\text { (T4) three } \\
\text { years. }\end{array}$ & $\begin{array}{l}\text { Gait speed distributions was different } \\
\text { in the subjects when cognitively } \\
\text { intact and when having MCl. } \\
\text { Transitioning to MCl, daily activities } \\
\text { were less distinguishable and often } \\
\text { occurred later. }\end{array}$ \\
\hline $\begin{array}{l}\text { Buchman } \\
\text { et al. [73], } \\
2019 .\end{array}$ & $\begin{array}{l}\text { Longitudinal cohort } \\
\text { study. }\end{array}$ & $\begin{array}{l}\text { Older adults: } n= \\
1249.80 .0 \text { years } \\
\text { old. }\end{array}$ & $\begin{array}{l}\text { MCl: } \\
- \text { MMSE > } \\
\quad 24 \text { [49]. }\end{array}$ & $\begin{array}{l}\text { Walking at their self- } \\
\text { selected Speed }(10 \mathrm{~m}) \text {. } \\
\text { TUG. } \\
\text { Standing Posture with } \\
\text { closed eyes. }\end{array}$ & $\begin{array}{l}\text { Wearable sensor } \\
\text { on the lower } \\
\text { back. }\end{array}$ & $\begin{array}{l}(\mathrm{T} 1) \text { at } \\
\text { baseline; } \\
\text { (T2) } \\
\text { during } 3.6 \\
\text { years. }\end{array}$ & $\begin{array}{l}\downarrow \text { Cadence and regularity were } \\
\text { associated with incident MCl }{ }^{* *} \text {. } \\
\text { Gait speed and gait variability were } \\
\text { not associated with incident } \mathrm{MCl}{ }^{*} \text {. }\end{array}$ \\
\hline
\end{tabular}

MCI Mild cognitive impairment, CDR Clinical Dementia Rating score, MMSE Mini-mental State Examination, HR Cox proportional Hazard, CI Confidence Interval, NS Not Specified, COV Coefficient of variation

$\uparrow$ Higher. $\downarrow$ Decreased

${ }^{*} p>0.05 .{ }^{* *} p<0.05$. ${ }^{* * *} p<0.001$

Table 4 Instruments used in kinematic analysis

\begin{tabular}{|c|c|c|}
\hline Instrument & Papers n, \% & References \\
\hline Tri-axial accelerometer (e.g. Locometrix ${ }^{\circledast}$, etc.) & $4,23.5 \%$ & {$[56,60,63,70]$} \\
\hline Electronic walkway (e.g. GAITRite ${ }^{\oplus}$, etc.) & $4,23.5 \%$ & {$[57,59,68,69]$} \\
\hline Wearable sensors & $2,12 \%$ & {$[58,73]$} \\
\hline $\begin{array}{l}\text { Digital Balance } \\
\text { Platform }\end{array}$ & $1,6 \%$ & [59] \\
\hline Inertial measurement units (IMUs) & $1,6 \%$ & [61] \\
\hline Motion and contact sensors & $4,23.5 \%$ & {$[64,67,71,72]$} \\
\hline Qualisys ProReflex motion analysis System (cameras) & $1,6 \%$ & [65] \\
\hline GAIT Up System. & $1,6 \%$ & [62] \\
\hline
\end{tabular}


Table 5 Criteria for $\mathrm{MCl}$ diagnosis reported in studies

\begin{tabular}{lll}
\hline Criteria & Papers n, $\%$ & References \\
\hline Petersen et al. [11, 12, 14-16] & $7,41 \%$ & {$[56-59,63,67,69]$} \\
Winblad et al. [13] & $2,12 \%$ & {$[60,70]$} \\
CDR [41] & $9,53 \%$ & {$[63-65,67-72]$} \\
MoCA [42] & $5,29 \%$ & {$[59,61,62,68,69]$} \\
MMSE [44] & $11,65 \%$ & {$[56,59,60,63-65,67,69-71,73]$} \\
Pfeiffer [60] & $1,6 \%$ & {$[65]$} \\
\hline
\end{tabular}

MCI Mild Cognitive Impairment, CDR Clinical Dementia Rating, MoCA Montreal Cognitive Assessment, MMSE Mini-Mental State Examination

findings of this review. Findings of this systematic review also could be useful for promoting specific interventions which could revert the functional changes associated with MCI, since RCTs included in this systematic review have demonstrated that physical activity interventions could improve some functional objective parameters.

\section{Implications for further research}

Despite the promising results of the present study, some flaws observed in most of the included studies in this review should be resolved. Hence, there are some recommendations to guide future research: (i) studies should use the same instrument to perform the kinematic analysis which would allow a better comparison of data between studies; (ii) these instruments should be valid and reliable as established in the Cosmin taxonomy; (iii) RCTs and Cohort studies with high quality of evidence should be conducted since studies included in this systematic review often showed an unclear risk of bias and a low quality of evidence; (iv) Clinical trials which use functional objective parameters as outcome measures of physical activity interventions in $\mathrm{MCI}$ also should be conducted.

\section{Conclusion}

Slower gait speed in ST condition and, above all, in DT conditions and larger gait speed variability are the parameters that best discriminate patients with $\mathrm{MCI}$ from a control group. Slower gait speed and larger gait variability may also predict an incident MCI or could even help its early diagnosis. Some functional objective parameters such as gait speed, stride length, stride time, balance and the time to perform the TUG may be improved by aerobic exercises when aerobic exercises are performed alongside cognitive stimulation exercises or others physical exercises such as muscle strength training, postural balance retraining, or gait training. Although most of the cohort studies showed a low risk of bias, RCTs reported unclear risk of bias and GRADE criteria showed a low level of evidence per outcome, so further studies are required to confirm our findings.

\section{Supplementary information}

Supplementary information accompanies this paper at https://doi.org/10. 1186/s12877-020-01678-6.

Additional file 1 Supplementary Appendix A. PRISMA Checklist. It includes the PRISMA checklist with the item reported in this trial.

Additional file 2 Supplementary Appendix B. Search Strategy. It includes the complete search strategy which was carried out with all search terms.

Additional file 3 Supplementary Appendix C. Checklist for selection of studies. It shows a checklist conducted to select studies which could be included in the present trial.

Additional file 4 Supplementary Appendix D. Excluded studies in the second screening. It contains references of excluded studies in the second screening since they did not meet inclusion criteria.

Additional file 5 Supplementary Appendix E. Conflict of interest of included studies. It shows the conflict of interests of included studies in the results.

Additional file 6 Supplementary Table 1. Methodological Quality of included RCT (The Cochrane Collaboration's tool). It includes the risk of bias of RCTs included in the manuscript.

Additional file 7 Supplementary Table 2. Methodological Quality of included prospective longitudinal studies (The Newcastle Ottawa Scale (NOS)). It shows the risk of bias of included prospective non-randomized longitudinal studies.

Additional file 8 Supplementary Table 3. Summary of findings and Quality of evidence assessment (GRADE). It contains the quality of the evidence of each outcome informed at least by two studies with the same design based on the GRADE criteria.

\section{Abbreviations}

MCl: Mild Cognitive Impairment; AMED: The Allied and Complementary Medicine Database; CINAHL: Cumulative Index to Nursing and Allied Health Literature; PEDro: Physiotherapy Evidence Database; RCTs: Randomized Controlled Trials; DT: Dual Task conditions; ADL: Activities of Daily Living; IADL: Instrumental Activities of Daily Living; SPPB: Short Physical Performance Battery; TUG: Timed Up and Go Test; HGST: Hand Grip Strength Test; STS: SitTo Stand Test; WST: Walking Speed Test; ST: Single Task condition; NOS: Newcastle-Ottawa Quality Assessment Scale; GRADE: Grading of Recommendations Assessment,Development and Evaluation; PRIS MA: Preferred Reporting Items for Systematic Reviews and Meta-Analyses; PROSPERO: International Prospective Register of Systematic Reviews; MeSH: Medical Subject Headings; CDR: Clinical Dementia Rating; MoCA: Montreal Cognitive Assessment; MMSE: Mini-Mental State Examination

Acknowledgements Not Applicable.

Authors' contributions

IJ-FA and A-CV contributed to the conception of this study. IJ-FA and A-CV were involved in the selection of the included studies. IJ-FA, A-CV, B-S, LM- 
$P B, M R-B L$ and $R-G H$ were involved in the writing and in the review of the manuscript. The authors have read and approved the manuscript.

\section{Funding}

Brendon Stubbs is supported by a Clinical Lectureship (ICA-CL-2017-03-001) jointly funded by Health Education England (HEE) and the National Institute for Health Research (NIHR). Brendon Stubbs is part funded by the NIHR Biomedical Research Centre at South London and Maudsley NHS Foundation Trust. Brendon Stubbs is also supported by the Maudsley Charity, King's College London and the NIHR South London Collaboration for Leadership in Applied Health Research and Care (CLAHRC) funding. This paper presents independent research. The views expressed in this publication are those of the authors and not necessarily those of the acknowledged institutions. María Rosa Bernal-López was supported by "Miguel Servet Type I" program (CP15/00028) from the ISCIII-Madrid (Spain), cofinanced by the Fondo Europeo de Desarrollo Regional-FEDER.

\section{Availability of data and materials}

Not Applicable - this manuscript does not contain any data.

\section{Ethics approval and consent to participate}

Not Applicable-this manuscript does not report on or involve the use of any animal or human data or tissue.

\section{Consent for publication}

Not Applicable-this manuscript does not contain data from any individual person.

\section{Competing interests}

The authors declare that they have no competing interests.

\section{Author details}

${ }^{1}$ Department of Physiotherapy, Faculty of Health Science, University ofMálaga. Biomedical Research Institute of Malaga (IBIMA), Clinimetric Group FE-14, Málaga, Spain. Av/ Arquitecto Peñalosa s/n (Teatinos Campus Expansion), 29071 Malaga, Spain. ${ }^{2}$ Physiotherapy Department, South London and Maudsley NHS Foundation Trust, Denmark Hill, London, UK. ${ }^{3}$ Department of Psychological Medicine, Institute of Psychiatry, Psychology and Neuroscience, King's College London, London, UK. ${ }^{4}$ Positive Ageing Research Intitute (PARI), Faculty of Health Social Care and Education, Anglia Ruskin University, Chelmsford, UK. ${ }^{5}$ Internal Medicine Department, Instituto de Investigación Biomédica de Malaga (IBIMA), Regional University Hospital of Málaga, Málaga, Spain. ${ }^{6}$ Unidad de Neurofisiología Cognitiva, Centro de Investigaciones Médico Sanitarias (CIMES), Instituto de Investigación Biomédica de Málaga (IBIMA), Universidad de Málaga (UMA), Campus de Excelencia Internacional (CEI) Andalucía Tech, Málaga, Spain. ${ }^{7}$ Centro de Investigación Biomédica en Red Enfermedades Cardiovasculares (CIBERCV), Instituto de Salud Carlos III, Madrid, Spain. ${ }^{8}$ CIBER Fisio-patología de la Obesidad y la Nutrición, Instituto de Salud Carlos III, Madrid, Spain. ${ }^{9}$ School of Clinical Sciences, Faculty of Health at the Queensland University of Technology, Brisbane, Queensland, Australia.

Received: 13 December 2019 Accepted: 27 July 2020 Published online: 10 August 2020

\section{References}

1. Abajobir AA, Abate KH, Abbafati C, Abbas KM, Abd-Allah F, Abdulkader RS, et al. Global, regional, and national disability-adjusted life-years (DALYs) for 333 diseases and injuries and healthy life expectancy (HALE) for 195 countries and territories, 1990-2016: a systematic analysis for the global burden of disease study 2016. Lancet. 2017;390(10100):1260-344.

2. Abajobir AA, Abbafati C, Abbas KM, Abd-Allah F, Abera SF, Aboyans V, et al. Global, regional, and national age-sex specific mortality for 264 causes of death, 1980-2016: a systematic analysis for the global burden of disease study 2016. Lancet. 2017;390(10100):1151-210.

3. Wang $\mathrm{H}$, Abajobir AA, Abate KH, Abbafati C, Abbas KM, Abd-Allah F, et al. Global, regional, and national under-5 mortality, adult mortality, age-specific mortality, and life expectancy, 1970-2016: a systematic analysis for the global burden of disease study 2016. Lancet. 2017;390(10100):1084-150.

4. Hoffman C, Rice D, Sung HY. Persons with chronic conditions: their prevalence and costs. JAMA. 1996;276(18):1473-9.
5. Cornelis E, Gorus E, Beyer I, Bautmans I, De Vriendt P. Early diagnosis of mild cognitive impairment and mild dementia through basic and instrumental activities of daily living: development of a new evaluation tool. PLoS Med. 2017:14(3):1-22.

6. Ferretti-Rebustini RE d L, Balbinotti MAA, Jacob-Filho W, Rebustini F, Suemoto CK, Pasqualucci CAG, et al. Validity of the Katz index to assess activities of daily living by informants in neuropathological studies. Rev Esc Enferm USP. 2015:49(6):946-52.

7. Limongi F, Siviero P, Noale M, Gesmundo A, Crepaldi G, Maggi S. Prevalence and conversion to dementia of mild cognitive impairment in an elderly Italian population. Aging Clin Exp Res. 2017;29(3):361-70.

8. Langa K, Levine D. The diagnosis and Management of Mild Cognitive Impairment: a clinical review. JAMA. 2014;312(23):2551-61.

9. Brodaty H, Aerts L, Crawford JD, Heffernan M, Kochan NA, Reppermund S, et al. Operationalizing the diagnostic criteria for mild cognitive impairment: the salience of objective measures in predicting incident dementia. Am J Geriatr Psychiatry. 2017:25(5):485-97.

10. Roberts R, Knopman DS. Classification and epidemiology of $\mathrm{MCl}$. Clin Geriatr Med. 2013;29(4). https://doi.org/10.1016/j.cger.2013.07.003.

11. Petersen RC. Mild cognitive impairment as a diagnostic entity. J Intern Med. 2004:256(9):183-94.

12. Petersen RC, Caracciolo B, Brayne C, Gauthier S, Jelic V, Fratiglioni L. Mild cognitive impairment: a concept in evolution. J Intern Med. 2014;275(3): 214-28.

13. Winblad B, Palmer K, Kivipelto M, Jelic V, Fratiglioni L, Wahlund L-O, et al. Mild cognitive impairment--beyond controversies, towards a consensus: report of the international working group on mild cognitive impairment. J Intern Med. 2004;256(3):240-6.

14. Petersen RC, Smith GE, Waring SC, Ivnik RJ, Tangalos EG, Kokmen E. Mild cognitive impairment: clinical characterization and outcome. Arch Neurol. 1999;56(3):303-8.

15. Petersen RC, Doody R, Kurz A, Mohs RC, Morris JC, Rabins PV, et al. Current concepts in mild cognitive impairment. Arch Neurol. 2001;58:1985-92.

16. Petersen R, Morris J. Mild cognitive impairment as a clinical entity and treatment target. Arch Neurol. 2005;62(7):1160-3.

17. Sachs-Ericsson N, Blazer DG. The new DSM-5 diagnosis of mild neurocognitive disorder and its relation to research in mild cognitive impairment. Aging Ment Health. 2015;19(1):2-12.

18. Lin JS, O'Connor E, Rossom RC, Perdue LA, Eckstrom E. Screening for cognitive impairment in older adults: a systematic review for the U.S. preventive services task force. Ann Intern Med. 2013;159(9):601-12.

19. Mitchell AJ, Beaumont H, Ferguson D, Yadegarfar M, Stubbs B. Risk of dementia and mild cognitive impairment in older people with subjective memorycomplaints: meta-analysis. Acta Psychiatr Scand. 2014;130(6):439-51.

20. Petersen RC, Knopman DS, Boeve BF, Yonas E, Ivnik RJ, Smith GE, et al. Mild cognitive impairment: ten years later. Arch Neurol. 2009;66(12):1447-55.

21. Portet F. Mild cognitive impairment $(\mathrm{MCl})$ in medical practice: a critical review of the concept and new diagnostic procedure. Report of the $\mathrm{MCl}$ working Group of the European Consortium on Alzheimer's disease. J Neurol Neurosurg Psychiatry. 2006;77(6):714-8 [cited 2019 Jan 21]. Available from: http://jnnp.bmj.com/cgi/doi/10.1136/jnnp.2005.085332.

22. Lee $\mathrm{SH}$, Han $J H$, Jin $Y Y$, Lee $H$, Hong HR, Kang HS. Poor physical fitness is independently associated with mild cognitive impairment in elderly Koreans. Biol Sport. 2016;33(1):57-62.

23. Waite LM, Grayson DA, Piquet $O$, Creasey H, Bennett HP, Broe GA. Gait slowing as a predictor of incident dementia: 6-year longitudinal data from the Sydney older persons study. J Neurol Sci. 2005;229-230:89-93.

24. Buracchio T, Dodge H, Howieson D, Wasserman D, Kaye J. The trajectory of gait speed preceding MCl. Arch Neurol. 2010;67(8):980-6.

25. Tseng B, Cullum C, Zhang R. Older adults with amnestic mild cognitive impairment exhibit exacerbated gait slowing under dual-task challenges. Curr Alzheimer Res. 2014;11(5):494-500 [cited 2019 Feb 12]. Available from: http://www.eurekaselect.com/openurl/content.php?genre=article\&issn=156 7-2050\&volume $=11$ \&issue $=5 \&$ spage $=494$.

26. Montero-Odasso M, Muir SW, Speechley M. Dual-task complexity affects gait in people with mild cognitive impairment: the interplay between gait variability, dual tasking, and risk of falls. Arch Phys Med Rehabil. 2012;93(2):293-9.

27. Gillain S, Warzee E, Lekeu F, Wojtasik V, Maquet D, Croisier JL, et al. The value of instrumental gait analysis in elderly healthy, $\mathrm{MCl}$ or Alzheimer's disease subjects and a comparison with other clinical tests used in single and dual-task conditions. Ann Phys Rehabil Med. 2009;52(6):453-74. 
28. Aggarwal NT, Wilson RS, Beck TL, Bienias JL, Bennett DA. Motor dysfunction in mild cognitive impairment and the risk of incident Alzheimer disease. Arch Neurol. 2006;63(12):1763-9.

29. Verghese J, Robbins M, Holtzer R, Zimmerman M, Wang C, Xue X, et al. Gait dysfunction in mild cognitive impairment syndromes. J Am Geriatr Soc. 2009:56(7):1244-51.

30. Veronese N, Stubbs B, Trevisan C, Bolzetta F, De Rui M, Solmi M, et al. What physical performance measures predict incident cognitive decline among intact older adults? A 4.4 year follow up study. Exp Gerontol. 2016;81:110-8.

31. Mielke MM, Roberts RO, Savica R, Cha R, Drubach DI, Christianson T, et al. Assessing the temporal relationship between cognition and gait: slow gait predicts cognitive decline in the Mayo Clinic study of aging. J Gerontol Med Sci. 2013;68(8):929-37.

32. Ojagbemi A, Este CD, Verdes E, Chatterji S, Gureje O. Gait \& Posture Gait speed and cognitive decline over 2 years in the Ibadan study of aging. Gait Posture. 2015;41(2):736-40.

33. Verghese J, Wang C, Lipton RB, Holtzer R, Xue X. Quantitative gait dysfunction and risk of cognitive decline and dementia. J Neurol Neurosurg Psychiatry. 2007;78(9):929-35.

34. Doi T, Shimada H, Park H, Makizako H, Tsutsumimoto K, Uemura K, et al. Cognitive function and falling among older adults with mild cognitive impairment and slow gait. Geriatr Gerontol Int. 2015;15(8):1073-8.

35. Eggermont LH, Gavett BE, Volkers KM, Blankevoort CG, Scherder EJ, Jefferson $\mathrm{AL}$, et al. Lower-extremity function in cognitively healthy aging, mild cognitive impairment, and Alzheimer's disease. Arch Phys Med Rehabil. 2010 Apr;91(4):584-8.

36. Deshpande N, Metter EJ, Bandinelli S, Guralnik J, Ferrucci L. Gait speed under varied challenges and cognitive decline in older persons: a prospective study. Age Ageing. 2009;38(5):509-14.

37. Narazaki K, Matsuo E, Honda T, Nofuji Y, Yonemoto K, Kumagai S. Physical fitness measures as potential markers of low cognitive function in Japanese community-dwelling older adults without apparent cognitive problems. J Sports Sci Med. 2014 Sep 1;13(3):590-6.

38. Ansai JH, de Andrade LP, Rossi PG, Nakagawa TH, Vale FAC, Rebelatto JR Differences in timed up and go subtasks between older people with mild cognitive impairment and mild Alzheimer's disease. Motor Control. 2019 Jan 1;23(1):1-12. https://doi.org/10.1123/mc.2017-0015.

39. Mirelman A, Weiss A, Buchman AS, Bennett DA, Nir Giladi JMH. Association between performance on timed up and go subtasks and mild cognitive impairment: further insights into the links between cognitive and motor function. J Am Geriatr Soc. 2014;62(4):673-8.

40. Bahureksa L, Najafi B, Saleh A, Sabbagh M, Coon D, Mohler J, et al. The impact of mild cognitive impairment on gait and balance: a systematic review and meta-analysis of studies using instrumented assessment. Gerontology. 2017;28(2):180-7.

41. Cuesta-Vargas Al, Galán-Mercant A, Williams JM. The use of inertial sensors system for human motion analysis. Phys Ther Rev. 2010;15(6):462-73.

42. Han JW, Lee H, Hong JW, Kim K, Kim T, Byun HJ, et al. Multimodal cognitive enhancement therapy for patients with mild cognitive impairment and mild dementia: a multi- center, randomized, controlled, double-blind, crossover trial. J Alzheimers Dis. 2017;55(2):787-96.

43. Panza GA, Taylor BA, Macdonald HV, Johnson BT, Zaleski AL, Livingston J, et al. Can exercise improve cognitive symptoms of Alzheimer's disease? A meta-analysis. J Am Geriatr Soc. 2018;66(3):487-95.

44. Hagovská M, Olekszyová Z. Impact of the combination of cognitive and balance training on gait, fear and risk of falling and quality of life in seniors with mild cognitive impairment. Geriatr Gerontol Int. 2016 Sep;16(9):1043-50.

45. Liberati A, Altman DG, Tetzlaff J, Mulrow C, Gotzsche PC, loannidis JP, et al. The PRISMA statement for reporting systematic reviews and meta-analyses of studies that evaluate healthcare interventions: explanation and elaboration. BMJ. 2009;339:b2700.

46. Morris JC. The clinical dementia rating (CDR): current version and scoring rules. Neurology. 1993;43:2412-4

47. Nasreddine ZS, Phillips NA, Bédirian V, et al. The Montreal cognitive assessment, MoCA: a brief screening tool for mild cognitive impairment. J Am Geriatr Soc. 2005;53:695-9.

48. Ciesielska N, Sokołowski R, Mazur E, Podhorecka M, Polak-Szabela A, Kędziora-Kornatowska K. Is the Montreal cognitive assessment (MoCA) test better suited than the mini-mental state examination (MMSE) in mild cognitive impairment (MCl) detection among people aged over 60? Metaanalysis. Psychiatr Pol. 2016;50(5):1039-52.
49. Folstein MF, Folstein SE, McHugh PR. Mini-mental state: a practical method for grading the state of patients for the clinician. J Psychiatr Res. 1975;12: 189-98.

50. Tombaugh TN, Mclntyre NJ. The mini-mental state examination: a comprehensive review. J Am Geriatr Soc. 1992;40:922-35.

51. Mitchell AJ. A meta-analysis of the accuracy of the mini-mental state examination in the detection of dementia and mild cognitive impairment. J Psychiatr Res. 2009;43(4):411-31.

52. Cacho J, Benito-León J, García-García R, Fernández-Calvo B, Vicente-Villardón $J$, Mitchell AJ. Does the combination of the MMSE and clock drawing test (mini-clock) improve the detection of mild Alzheimer's disease and mild cognitive impairment? J Alzheimers Dis. 2010;22(3):889-96.

53. Wells GA, Shea B, O'Connell D, Peterson J, Welch V, Losos M, et al. The Newcastle-Ottawa scale (NOS) for assessing the quality of non-randomised studies in meta-analyses; 2009. [cited 2019 September 24]. Available from: http://www.ohri.ca/programs/clinical_epidemiology/oxford.asp.

54. Higgins JPT, Altman DG, Gøtzsche PC, Jüni P, Moher D, Oxman AD, et al. The Cochrane Collaboration's tool for assessing risk of bias in randomised trials. BMJ. 2011;343:d5928.

55. Atkins $D$, Best $D$, Briss PA, et al. Grading quality of evidence and strength of recommendations. BMJ. 2004;328:1490. https://doi.org/10.1136/bmj.328. 7454.1490 [PMC free article] [PubMed].

56. Doi T, Makizako H, Shimada H, Yoshida D, Tsutsumimoto K, Sawa R, et al. Effects of multicomponent exercise on spatial-temporal gait parameters among the elderly with amnestic mild cognitive impairment (aMCl): preliminary results from a randomized controlled trial (RCT). Arch Gerontol Geriatr. 2013;56(1):104-8 [cited 2019 Mar 13]. Available from: https:// linkinghub.elsevier.com/retrieve/pii/S0167494312002002.

57. Donnezan LC, Perrot A, Sylvie Belleville FB, Kemoun G. Effects of simultaneous aerobic and cognitive training on executive functions, cardiovascular fitness and functional abilities in older adults with mild cognitive impairment. Ment Health Phys Act. 2018;15:78-87. https://doi.org/ 10.1016/j.mhpa.2018.06.001.

58. Schwenk M, Sabbagh M, Lin I, Morgan P, Grewal GS, Mohler J, et al. Sensorbased balance training with motion feedback in people with mild cognitive impairment. J Rehabil Res Dev. 2016;53(6):945-58.

59. Fogarty JN, Murphy KJ, McFarlane B, Montero-Odasso M, Wells J, Troyer AK, et al. Taoist tai chi ${ }^{\oplus}$ and memory intervention for individuals with mild cognitive impairment. J Aging Phys Act. 2016 Apr;24(2):169-80.

60. Bae S, Sangyoon Lee SL, Jung S, Makino K, Kazuhiro Harada K, Harada YS, et al. The effect of a multicomponent intervention to promote community activity on cognitive function in older adults with mild cognitive impairment: a randomized controlled trial. Complement Ther Med. 2018:42:164-9.

61. Delbroek T, Vermeylen W, Spildooren J. The effect of cognitive-motor dual task training with the biorescue force platform on cognition, balance and dual task performance in institutionalized older adults: a randomized controlled trial. J Phys Ther Sci. 2017;29(7):1137-43.

62. Liao Y-Y, Chen $\mathrm{H}-\mathrm{H}$, Lin Y-J, Chen Y, Hsu W-C. Effects of virtual reality-based physical and cognitive training on executive function and dual-task gait performance in older adults with mild cognitive impairment: a randomized control trial. Front Aging Neurosci. 2019;11:162.

63. Gillain S, Dramé M, Lekeu F, Wojtasik V, Ricour C, Croisier J-L, et al. Gait speed or gait variability, which one to use as a marker of risk to develop Alzheimer disease? A pilot study. Aging Clin Exp Res. 2015;28(2):249-55 [cited 2019 Mar 19]. Available from: http://link.springer.com/10.1007/s40520015-0392-6.

64. Tamara L, Hayes FA, Adami A, Pavel M, Zitzelberger JAK TA. Unobtrusive assessment of activity patterns associated with mild cognitive impairment. Alzheimers Dement. 2008;4(6):395-405.

65. Ansai JH, de Andrade LP, Nakagawa TH, Rebelatto JR. Performances on the timed up and go test and subtasks between fallers and non-fallers in older adults with cognitive impairment. Arq Neuropsiquiatr. 2018;76(6):381-6.

66. Pfeiffer E. A short portable mental status questionnaire for the assessment of organic brain deficit in elderly patients. J Am Geriatr Soc. 1975;23(10): 433-41.

67. Dodge HH, Mattek NC, Austin D, Hayes TL, Kaye JA. In-home walking speeds and variability trajectories associated with mild cognitive impairment. Neurology. 2012 Jun 12;78(24):1946-52.

68. Pieruccini-Faria F, Sarquis-Adamson Y, Montero-Odasso M. Mild cognitive impairment affects obstacle negotiation in older adults: results from "gait and brain study". Gerontology. 2019;65(2):164-73. 
69. Montero-Odasso M, Alvaro Casas KTH, Bilski P, Iris Gutmanis JLW, M JB. Quantitative gait analysis under dual-task in older people with mild cognitive impairment: a reliability study. J Neuroeng Rehabil. 2009;6:35.

70. Byun S, Han JW, Kim TH, Kim K, Kim TH, Park JY, et al. Gait variability can predict the risk of cognitive decline in cognitively Normal older people. Dement Geriatr Cogn Disord. 2018;45(5-6):251-61.

71. Akl A, Taati B, Mihailidis A. Autonomous unobtrusive detection of mild cognitive impairment in older adults. IEEE Trans Biomed Eng. 2015 May; 62(5):1383-94.

72. Akl A, Mihailidis A. Estimating in-home walking speed distributions for unobtrusive detection of mild cognitive impairment in older adults. In: 37th annual international conference of the IEEE engineering in medicine and biology society (EMBC); 2015. p. 5175-8.

73. Buchman A-S, Dawe R-J, Leurgans S-E, Curran T-A, Truty T, Yu L, et al. Different combinations of mobility metrics derived from a wearable sensor are associated with distinct health outcomes in older adults. J Gerontol A Biol Sci Med Sci. 2020;75(6):1176-83. https://doi.org/10.1093/gerona/glz160.

74. Lussier M, Lavoie M, Giroux S, Consel C, Guay M, Macoir J, et al. Early detection of mild cognitive impairment with in-home monitoring technologies using functional measures: a systematic review. IEEE J Biomed Heal Informatics. 2019;23(2):838-47.

75. Lamoth CJ, van Deudekom FJ, van Campen JP, Appels BA, de Vries OJ Pijnappels M. Gait stability and variability measures show effects of impaired cognition and dual tasking in frail people. J Neuroeng Rehabil. 2011;8:2-2

76. Schwenk M, Zieschang T, Englert S, Grewal G, Najafi B, Hauer K. Improvements in gait characteristics after intensive resistance and functional training in people with dementia: a randomised controlled trial. BMC Geriatr. 2014;14:73.

77. Gomes-Osman J, Cabral DF, Morris TP, Mclnerney K, Cahalin LP, Rundek T, et al. Exercise for cognitive brain health in aging. Neurol Clin Pract. 2018; 8(3):257-65.

78. Karssemeijer EGA, Aaronson JA, Bossers WJ, Smits T, Rikkert MGM, Kessels RPC. Positive effects of combined cognitive and physical exercise training on cognitive function in older adults with mild cognitive impairment or dementia: a meta-analysis. Ageing Res Rev. 2017 Nov;40:75-83.

79. Song D, Yu DSF, Li PWC, Lei Y. The effectiveness of physical exercise on cognitive and psychological outcomes in individuals with mild cognitive impairment: a systematic review and meta-analysis. Int J Nurs Stud. 2018;79: 155-64.

80. Wang C, Yu J-T, Wang H-F, Tan C-C, Meng X-F, Tan L. Non-pharmacological interventions for patients with mild cognitive impairment: a meta-analysis of randomized controlled trials of cognition-based and exercise interventions. J Alzheimers Dis. 2014 Aug 28;42(2):663-78.

81. Najafi B, Helbostad JL, Moe-Nilssen R, Zijlstra W, Aminian K. Does walking strategy in older people change as a function of walking distance? Gait Posture. 2009:29:261-6.

\section{Publisher's Note}

Springer Nature remains neutral with regard to jurisdictional claims in published maps and institutional affiliations.

Ready to submit your research? Choose BMC and benefit from:

- fast, convenient online submission

- thorough peer review by experienced researchers in your field

- rapid publication on acceptance

- support for research data, including large and complex data types

- gold Open Access which fosters wider collaboration and increased citations

- maximum visibility for your research: over $100 \mathrm{M}$ website views per year

At $\mathrm{BMC}$, research is always in progress.

Learn more biomedcentral.com/submissions 